\title{
Correlation and Path Coefficient Analyses of Seed Yield and its Contributing Traits in Cajanus cajan (L.) Millsp
}

\author{
O. Udensi ${ }^{1^{\star}}$ and E. V. Ikpeme ${ }^{1}$ \\ ${ }^{1}$ Department of Genetics and Biotechnology, University of Calabar, P.M.B 1115, \\ Calabar, Nigeria.
}

Research Article

Received $20^{\text {th }}$ October 2011

Accepted $18^{\text {th }}$ January 2012

Online Ready $12^{\text {th }}$ April 2012

\section{ABSTRACT}

Aims: It is utmost desire for plant breeders to know the extent of relationship between yield and its various components, which will inevitably facilitate selection of desirable characteristics. This research focused on computing the correlation coefficients and path coefficients of yield and its contributing traits in pigeon pea landraces Cajanus cajan (L.) Millsp.

Methods: Seeds of two varieties of locally grown pigeon pea were sown in a randomized complete block design (RCBD) in ten replications. The field study was done at the University of Calabar Experimental Farm, University of Calabar, Calabar, South-South, Nigeria, during the 2009-2010 growing season. Correlation coefficients and path coefficients (partitioned into direct and indirect effects) were estimated on yield and its contributing traits.

Results: Correlation results revealed that there was significant positive correlations between plant height plant $^{-1}$ and number of leaves plant $^{-1}\left(0.926^{* *}\right)$, leaf area plant ${ }^{-1}$ $\left(0.574^{*}\right)$ and number of seeds plant ${ }^{-1}\left(0.616^{*}\right)$. It also showed that the number of leaves plant $^{-1}$ was positively correlated with the pod length plant $^{-1}\left(0.589^{*}\right)$ and number of seeds plant $^{-1}\left(0.682^{*}\right)$. Leaf area plant ${ }^{-1}$ had a positive significant association with the number of seeds plant ${ }^{-1}\left(0.581^{*}\right)$. Additionally, pod length plant $^{-1}$ correlated positively with the number

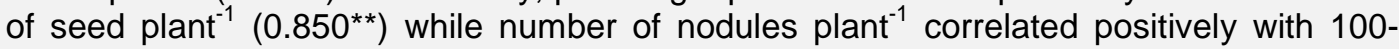
seed weight $\left(0.804^{\star *}\right)$. Path coefficient results showed that 100 -seed weight had the highest direct effect on yield (0.583), which was positive. This was followed by the pod length plant $^{-1}(0.519)$, number of leaves $(0.452)$, and leaf area $(0.252)$ while plant height plant $^{-1}$ had negative direct effect but very high $(-0.633)$. Number of pod plant ${ }^{-1}$ had the 
lowest direct effect on yield (0.033). Additionally, genotypic correlation coefficient with yield showed very high coefficients, especially for pod length plant $^{-1}(0.827), 100$-seed weight $(0.798)$, number of leaves plant ${ }^{-1}(0.644)$, plant height plant ${ }^{-1}(0.582)$ and leaf area plant ${ }^{-1}$ (0.549), respectively. Number of nodules plant $^{-1}$ had the lowest genotypic correlation coefficient $(0.042)$ followed by number of flowers plant $^{-1}(-0.063)$.

Conclusion: The two results from correlation and path coefficient analyses strongly suggest that plant height plant ${ }^{-1}$, number of leaves plant $^{-1}$, leaf area plant ${ }^{-1}$ and pod length plant $^{-1}$ and 100 - seed weight should be considered as indices for selecting high yielding pigeon pea genotypes, especially the landraces.

Keywords: Correlation; path coefficient; Pigeon pea landraces; selection.

\section{INTRODUCTION}

Pigeon pea [Cajanus cajan (L.) Millsp] is a multipurpose legume crop and is well adapted even in marginal lands (Joshi et al., 2009). According to the Center for New Crops and Products (2002), pigeon peas serve as important food and excellent protein source in developing tropical countries. Additionally, the seeds and sometimes the pods are eaten as vegetable and also used as flour additive in soups and rice. A species of bacteria, Rhizobia is capable of fixing 41 to $280 \mathrm{~kg} / \mathrm{ha}$ of nitrogen due to their intrinsic capacity to symbiotically associate with the root nodules of pigeon peas. Parrotta (2001) reported the use of their leaf preparations for the treatment of jaundice, inflammation and sores of the mouth.

The high adaptability, heritability, genetic variability and nutritive values reported of locally grown pulses (landraces) call for concerted efforts towards their genome manipulation and improvement. This notwithstanding, the need to complement these approach should not be overemphasized as more often than not, local farmers are deprived of these high yielding genotypes (Udensi et al., 2010, 2011a, 2011b).

Seed yield is the result of the expression and association of several plant growth components, which contribute additively or help in some conditions in modifying the expression of other traits directly or indirectly. Suffice it to say that the main objective for a plant breeder is to evolve high yielding varieties. It is therefore desirable for plant breeder to know the extent of relationship between yield and its various components, which will inevitably facilitate selection of desirable characteristics. Correlation and path coefficient become necessary tools at the disposal of the breeder.

Correlation measures the mutual association between two variables, which aids in determining the most effective procedures for selection of superior genotypes. When there is positive association of major yield traits component, breeding would be very effective but on the reverse, it becomes difficult to exercise simultaneous selection for them in developing a variety. According to Cramer and Wehner (2000a) the goal of indirect selection is to find yield components that have a strong direct effect on fruit number per plant with little negative influence from other yield components. Interestingly, path coefficient analysis can be employed to partition the correlation between yield components and yield into direct and indirect effects. Salahuddin et al. (2010) affirms that path coefficient analysis provides an effective means of partitioning correlation coefficients into unidirectional pathways and alternative pathways thus permitting a critical examination of specific factors that produce a 
given correlation, which can be successfully employed in formulating an effective selection programme.

There is little documentation regarding this technique. For instance, lqbal et al. (2003) reported the use of path coefficient analysis in soybean breeding while Yadev et al. (2001), Arshad et al. (2003), Ghafoor et al. (2003) and Arshad et al. (2004) have mentioned the worth of this techniques in other legumes. Cramer and Wehner (2000a) reported path coefficient in cucumber population while Akinyele and Osekita (2006) reported the result of path coefficient on Abelmoschus esculentus.

This research paper becomes necessary owing to the paucity of information on this technique, especially on pigeon pea, which will be guide to selecting superior genotypes.

\section{MATERIALS AND METHODS}

Seeds of two varieties of pigeon pea landraces commonly grown in south eastern Nigeria were obtained in Enugu State, Nigeria. A plot of land measuring 10×10 meters was manually cleared in the University of Calabar Experimental Farm, Calabar during the 2009-2010 growing season. Five beds were made with a spacing of 2 meters between beds. Three seeds were sown in a hole of $4 \mathrm{~cm}$ deep per variety (Center for New Crops and Plants Products, 2002) in randomized complete block design (RCBD) in 10 replicates per variety. Spacing of $20 \times 75 \mathrm{~cm}$ was maintained per variety. Thinning was done after seedling emergence where applicable to two stands. Weeding was done 3 and 5 weeks after planting. Data were collected every two months on plant height per plant, number of leaves per plant, leaf area per plant, number of flowers per plant; pod lengths, number of nodules, number of seeds per plant, number of pods per plant and 100-seed weight, respectively.

\subsection{Data Analysis}

Data obtained were subjected to correlation and path coefficient analysis using statistical software PASW Ver. 18.0. Path coefficient was taken as the standardized coefficient of regression (direct effect) while the indirect effect was computed by multiplying the path coefficient of individual traits with their corresponding correlation coefficients (Cramer and Wehner, 2000a). The residual effect was estimated using the formula according to Singh and Chaudhary (1985).

\section{RESULTS AND DISCUSSION}

\subsection{Correlation and Path Coefficient Analyses}

Result on Table 1 showed the correlation matrix of yield and yield-contributing traits in the pigeon pea. It revealed that there was significant positive correlations between plant height plant ${ }^{-1}$ and number of leaves plant ${ }^{-1}\left(0.926^{* \star}\right)$, leaf area plant ${ }^{-1}\left(0.574^{*}\right)$ and number of seeds plant $^{-1}\left(0.616^{*}\right)$. It also showed that the number of leaves plant ${ }^{-1}$ was positively correlated with the pod length plant ${ }^{-1}\left(0.589^{*}\right)$ and number of seeds plant ${ }^{-1}\left(0.682^{*}\right)$. Leaf area plant ${ }^{-1}$ had a positive significant association with the number of seeds plant ${ }^{-1}\left(0.581^{*}\right)$. Additionally, pod length plant ${ }^{-1}$ correlated positively with the number of seed plant ${ }^{-1}\left(0.850^{* *}\right)$ while number of nodules plant ${ }^{-1}$ correlated positively with 100 -seed weight $\left(0.804^{* *}\right)$. However, other relationships were not significant. The direct effect (path coefficient), indirect effect and the genotypic correlation coefficient of yield-influencing traits monitored in pigeon pea are presented on Table 2. 
Table 1. Correlation matrix of yield and yield related traits in Cajanus cajan (L.) Millsp

\begin{tabular}{|c|c|c|c|c|c|c|c|c|c|}
\hline Traits & $\begin{array}{l}\text { Plant height } \\
\text { plant }^{-1} \\
(\mathrm{~cm})\end{array}$ & $\begin{array}{l}\text { No. of } \\
\text { leaves } \\
\text { plant }^{-1}\end{array}$ & $\begin{array}{l}\text { Leaf area } \\
\text { plant }^{-1} \\
\left(\mathrm{~cm}^{2}\right)\end{array}$ & $\begin{array}{l}\text { No. of } \\
\text { flowers } \\
\text { plant }^{-1}\end{array}$ & $\begin{array}{l}\text { No. of } \\
\text { pod } \\
\text { plant }^{-1}\end{array}$ & $\begin{array}{l}\text { Pod length } \\
\text { plant }^{-1} \\
(\mathrm{~cm})\end{array}$ & $\begin{array}{l}\text { No. of } \\
\text { seeds } \\
\text { plant }^{-1}\end{array}$ & $\begin{array}{l}\text { No. of } \\
\text { nodules } \\
\text { plant }^{-1}\end{array}$ & $\begin{array}{l}\text { 100-seed } \\
\text { weight }(\mathrm{g})\end{array}$ \\
\hline Plant height plant $^{-1}$ & 1 & $0.926^{\star *}$ & $0.574^{*}$ & -0.409 & 0.011 & 0.516 & $0.616^{*}$ & 0.393 & 0.520 \\
\hline No. of leaves plant ${ }^{-1}$ & & 1 & 0.422 & -0.278 & 0.325 & $0.589^{*}$ & $0.682^{*}$ & 0.382 & 0.536 \\
\hline Leaf area plant $^{-1}$ & & & 1 & -0.206 & -0.321 & 0.244 & $0.581^{*}$ & 0.263 & 0.548 \\
\hline No. of flowers plant ${ }^{-1}$ & & & & 1 & 0.045 & -0.088 & -0.054 & 0.058 & 0.334 \\
\hline No. of pod plant ${ }^{-1}$ & & & & & 1 & 0.378 & 0.330 & -0.099 & 0.092 \\
\hline Pod length plant ${ }^{-1}$ & & & & & & 1 & $0.850^{* *}$ & 0.248 & 0.504 \\
\hline No. of seeds plant ${ }^{-1}$ & & & & & & & 1 & 0.129 & $0.804^{\star *}$ \\
\hline No. of nodule plant ${ }^{-1}$ & & & & & & & & 1 & 0.064 \\
\hline 100-seed weight & & & & & & & & & 1 \\
\hline
\end{tabular}

Table 2. Direct effect (underlined), indirect effect and genotypic correlation of yield-related traits with yield of Cajanus cajan (L.) Millsp

\begin{tabular}{|c|c|c|c|c|c|c|c|c|c|}
\hline Traits & $\begin{array}{l}\text { Plant height } \\
\text { plant }^{-1} \\
\text { (cm) }\end{array}$ & $\begin{array}{l}\text { No. of } \\
\text { leaves } \\
\text { plant }^{-1}\end{array}$ & $\begin{array}{l}\text { Leaf area } \\
\text { plant }^{-1} \\
\left(\mathrm{~cm}^{2}\right)\end{array}$ & $\begin{array}{l}\text { No. of } \\
\text { flowers } \\
\text { plant }^{-1}\end{array}$ & $\begin{array}{l}\text { No. of } \\
\text { pod } \\
\text { plant }^{-1}\end{array}$ & $\begin{array}{l}\text { Pod length } \\
\text { plant }^{-1}(\mathrm{~cm})\end{array}$ & $\begin{array}{l}\text { No. of } \\
\text { nodule } \\
\text { plant }^{-1}\end{array}$ & $\begin{array}{l}\text { 100-seed } \\
\text { weight } \\
\text { (g) }\end{array}$ & $\begin{array}{l}\text { Genotypic } \\
\text { correlation } \\
\text { with yield }\end{array}$ \\
\hline Plant height plant $^{-1}$ & -0.633 & 0.419 & 0.145 & 0.117 & 0.0004 & 0.268 & -0.037 & 0.303 & 0.5824 \\
\hline No. of leaves plant ${ }^{-1}$ & -0.586 & 0.452 & 0.106 & 0.079 & 0.011 & 0.306 & -0.036 & 0.312 & 0.644 \\
\hline Leaf area plant $^{-1}$ & -0.363 & 0.191 & 0.252 & 0.059 & -0.011 & 0.127 & -0.025 & 0.319 & 0.549 \\
\hline No. of flowers plant ${ }^{-1}$ & 0.259 & -0.126 & -0.052 & -0.285 & 0.001 & -0.05 & -0.005 & 0.195 & -0.063 \\
\hline No. of pod plant ${ }^{-1}$ & -0.007 & 0.147 & -0.081 & -0.013 & 0.033 & 0.193 & 0.009 & 0.054 & 0.338 \\
\hline Pod length plant $^{-1}$ & -0.327 & 0.266 & 0.061 & 0.025 & 0.012 & 0.519 & -0.023 & 0.294 & 0.827 \\
\hline No. of nodules plant ${ }^{-1}$ & -0.249 & 0.173 & 0.066 & -0.017 & -0.003 & 0.129 & -0.094 & 0.037 & 0.042 \\
\hline 100-seed weight & -0.329 & 0.242 & 0.138 & -0.095 & 0.003 & 0.262 & -0.006 & 0.583 & 0.798 \\
\hline
\end{tabular}

*other values are indirect effects via different pathways except the genotypic correlation with yield. 
It showed that different yield traits had varied magnitude of direct effects on yield. It was observed that 100-seed weight had the highest direct effect on yield $(0.583)$, which was positive. This was followed by the pod length plant $^{-1}(0.519)$, number of leaves $(0.452)$, leaf area $(0.252)$ while plant height plant ${ }^{-1}$ had negative direct effect but very high $(-0.633)$. Number of pod plant ${ }^{-1}$ had the lowest direct effect on yield (0.033) (Fig. 1). Additionally, genotypic correlation with yield showed very high coefficients, especially for pod length plant (0.827), 100-seed weight $(0.798)$, number of leaves plant ${ }^{-1}(0.644)$, plant height plant ${ }^{-1}$ $(0.582)$ and leaf area plant ${ }^{-1}(0.549)$ respectively. Number of nodules plant ${ }^{-1}$ had the lowest genotypic correlation coefficient $(0.042)$ followed by number of flowers plant ${ }^{-1}(-0.063)$. However, the residual effect to yield was 14 per cent (Fig. 1).

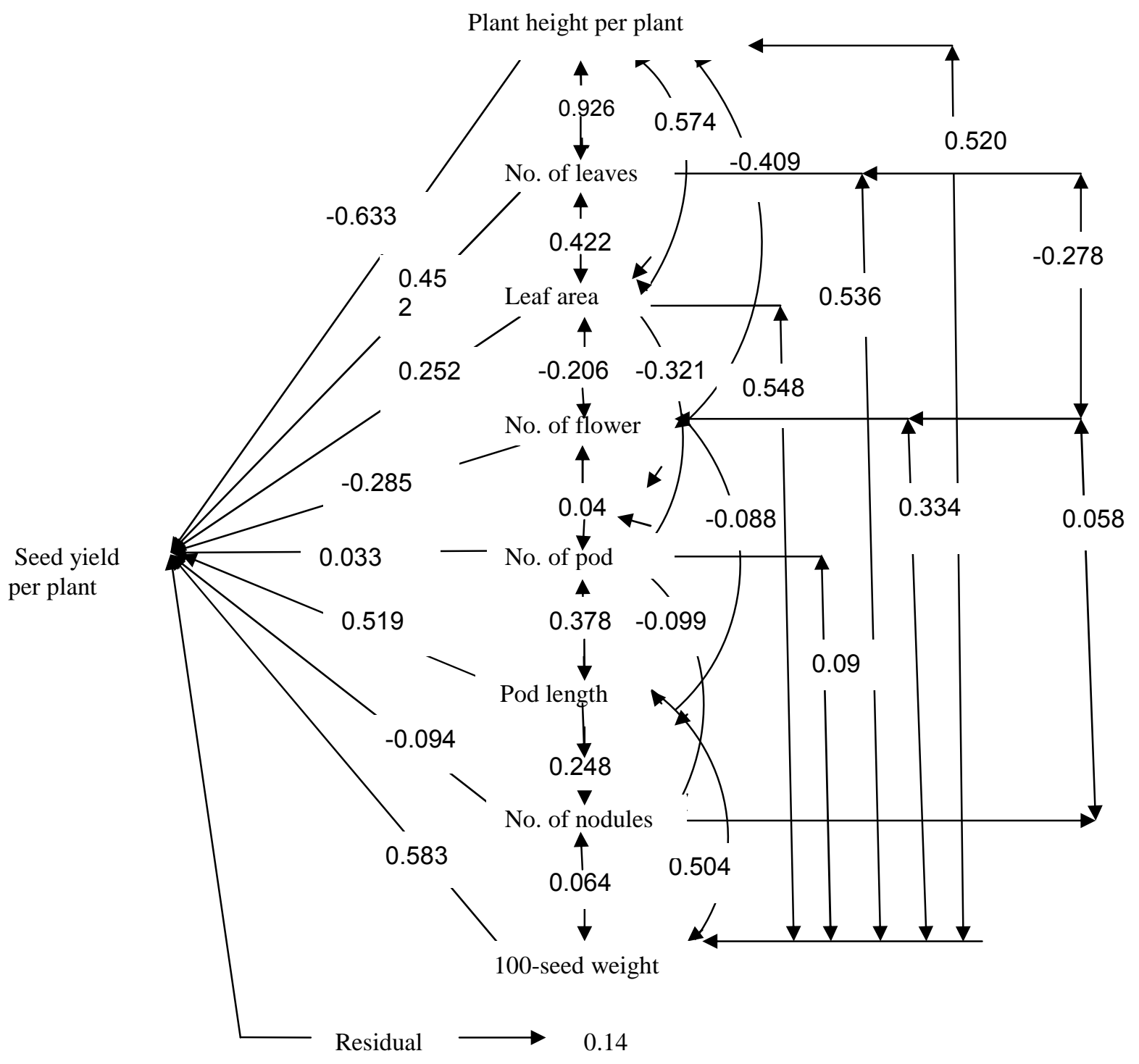

Fig. 1. Path diagram showing the path coefficients and correlation coefficients of yield and yield-related traits in locally grown pigeon pea varieties [Cajanus cajan (L.) Millsp] 


\subsection{Discussion}

It is obvious that the desire of plant breeders is to know the extent of relationship between yield and its various components, which will enhance their selection processes. Our correlation results showed significantly positive relationships between plant height plant ${ }^{-1}$ and number of leaves plant ${ }^{-1}$, leaf area plant ${ }^{-1}$ and number of seed plant ${ }^{-1}$, respectively. The deduction here is that as the crop increase in height, the number of leaves increase, which could due to the production of more branches. Since the leaves are better exposed to solar radiation owing to the broader leaf area, photosynthesis processes thus increase on the leaf surface with the resultant increase in productivity. This corroborates with the report of Akinyele and Osekita (2006) that height at flowering and final height are vegetative traits that are important for yield determination. Their facilitatory role contributes significantly to final yield and should be considered during selection to improve yield in breeding programme. According to Udensi et al. (2010) these traits seem to be functioning in tandem with one another. It however implies that direct selection of plant height might be advisable since it result in myriad of effects, including seed yield than direct selection for seed yield itself, particularly if the height has higher heritability than seed yield. The number of leaves plant ${ }^{-1}$, leaf area plant ${ }^{-1}$ and pod length plant $^{-1}$ had significant positive relationship with the number of seeds. This was also reported by Cramer and Wehner (2000a, 2000b). Although some of these characters that negative correlation with one another will be difficult to select for in characterization of desirable traits, those with negative association but non-significant correlation will be disregarded in selection for crop improvement (Henry and Krishna, 1990; Akinyele and Osekita, 2006).

The direct effects of 100-seed weight, number of leaves plant $^{-1}$, leaf area plant ${ }^{-1}$ and pod length plant ${ }^{-1}$ were positive while plant height plant ${ }^{-1}$, number of flowers plant ${ }^{-1}$ and number of nodules plant ${ }^{-1}$ were negative. 100-seed weight had the highest direct effect followed by pod length plant ${ }^{-1}$. These results are in conformity with the reports of Arshad et al. (2006), Shrivastava et al. (2001), Khan et al. (2000) and Singh and Yadava, (2000) in soybean. The positive direct effects of 100-seed weight to yield was also reported by Yadev et al. (2001) in wheat; Ashraf et al. (2002) in Urdbean; Arshad et al. (2004) in chicken pea and Arshad et al. (2006) in soybean.

According to Singh and Chaudhary (1985), if the correlation coefficient is positive but the direct effect is negative or negligible, the indirect effects might be the causal factor of correlation. It should be made clear that the correlation at this point is the genotypic correlation, which is derived from the addition of the direct and indirect effects (Table 2). Going by this premise therefore, since genotypic correlation for plant height plant ${ }^{-1}$ is 0.5824 while the direct effect is -0.633 , it does mean that alternative pathways (indirect routes) such as number of leaves plant ${ }^{-1}(0.419)$, leaf area plant ${ }^{-1}(0.145)$, pod length plant ${ }^{-1}(0.268)$, number of flower plant ${ }^{-1}(0.117)$ should be considered simultaneously for selection. This is in line with the submission of Salahuddin et al. (2010).

Cramer and Wehner (2000a) suggested a statistical test for the relative importance of path coefficient as 0.7 to 1.0 or -0.7 to -1.0 (strong coefficient) and -0.69 to 0.69 (weak coefficient). Although our present result did not corroborate with Cramer's test, however, other researchers in this field had reported good path coefficients as low as -0.03220 and 0.0544 in pigeon pea (Vange and Moses, 2009); 0.390, $0.431,0.190$ etc., in soybean (Arshad et al., 2006); 0.4260, 0.2177, 0.2264 etc., in okra (Akinyele and Osekita, 2006). The above reviews show that the number of leaves per plant, leaf area, pod length plant ${ }^{-1}$ and 100 -seed weight had significant direct influence on seed yield (Table 2). The implication is 
that direct selection programme of these traits would be beneficial for the breeding of this crop. One would have expected the number of pods plant ${ }^{-1}$ to contribute directly to yield. However, our result indicates that alternative pathways via number of leaves plant $^{-1}(0.147)$ and pod length plant ${ }^{-1}(0.196)$ should rather be considered for selection indirectly instead of direct selection through number of pods plant ${ }^{-1}$.

The path coefficient result confirms a natural condition one would have imagined. If the number of leaves plant ${ }^{-1}$ increase with broader surface, more surfaces will be exposed to radiant solar radiation thus increasing photosynthetic surface with more food production. This led to longer pod, resulting to enhanced seed yield. In order for the crop to produce many seed, plants must accumulate a large photosynthetic area to support the growth of a large number of seeds (Cramer and Wehner, 2000b). From the correlation analysis there was significant positive relationship between the plant height plant ${ }^{-1}$ and number of seed plant $^{-1}$. This result is in agreement with the result of the direct, indirect and genotypic correlation coefficient.

\section{CONCLUSION}

Our results suggest that the plant height plant ${ }^{-1}$, number of leaves plant ${ }^{-1}$, leaf area plant ${ }^{-1}$ and pod length plant ${ }^{-1}$ should be considered while selecting high yielding pigeon pea genotypes, especially the landraces. Additionally, path coefficient results explicitly indicate that the pod length plant ${ }^{-1}, 100$-seed weight, number of leaves plant ${ }^{-1}$ and leaf area plant ${ }^{1}$, which directly contributed substantially towards seed yield, should be indices for selection in pigeon pea. Interestingly, the correlation and path coefficients results are in agreement confirming the importance of these traits during selection.

\section{COMPETING INTERESTS}

Authors have declared that no competing interests exist.

\section{REFERENCES}

Akinyele, B.O., Osekita, O.S. (2006). Correlation and path coefficient analyses of seed yield attributes in okra [Abelmoschus esculentus (L.) Moench]. African Journal of Biotechnology, 5(14), 1330-1338.

Arshad, M., Bakhsh, A., Ghafoor A. (2004). Path coefficient analysis in chickpea (Cicer arietinum) under rainfed conditions. Pak. J. Bot., 36(1), 75-81.

Arshad, M.A., Bakhsh, A., Zubair M., Ghafoor, A. (2003). Genetic variability and correlation studies on chickpea (Cicer arietinum L.). Pak. J. Bot., 35(4), 605-611

Arshad, M., Ali, N., Ghafoor A. (2006). Character correlation and path coefficient in soybean Glycine max (L.) Merrill. Pak. J. Bot., 38(1), 121-130

Ashraf, M., Ghafoor, A., Khan, N.A., Yousaf, M. (2002). Path coefficient in wheat under unirrigated conditions. Pak. J. Agric. Res., 17(1), 1-6.

Center for New Crops and Plants Products. (2002). Cajanus cajan (L.) Millsp. Purdue University. http://www.hort.purdue.edu/newcrop/duke_energy/Cajanus_cajun.html.

Cramer, C.S., Wehner, T. C. (2000a). Path analysis of the correlation between fruit number and plant traits of cucumber populations. Hortscience, 35(4), 708-711

Cramer, C.S., Wehner, T.C. (2000b). Fruit yield and yield component correlations of four picking cucumber populations. Cucurbit Genet. Coop. Rpt., 23, 12-15 
Ghafoor, A., Gulbaaz, F.N., Afzal, M., Arshad, M. (2003). Inter-relationship between SDSPAGE markers and agronomic traits in chickpea (Cicer arietinum L.). Pak. J. Bot., 35(4), 613-624.

Henry, A., Krishna, G.V. (1990). Correlation and path coefficient analysis in pigeon pea. Madras Agric. J., 77(9,12), 443-446.

lqbal, S., Mahmood, T., Tahira, M., Ali, M., Anwar, M., Sarwar, M. (2003). Path analysis in mash (Vigna mungo L.). Pak. J. Bot., 22(2), 160-167

Joshi, B.K., Bimb, H.P., Gauchan, D., Bajracharya, J., Shrestha, P., Upadhyay, M.P. (2009). Genetic diversity and population structure of pigeon pea. BNS E- Bulletin, 1.

Khan, A., Hatam, M., Khan, A. (2000). Heritability and interrelationship among yield determining components of soybean varieties. Pak. J. Agric. Res., 116, 5-8.

Parrotta, J.A. (2001). Healing Plants of Peninsular India. CABI Publishing, Wallingford, New York.

Salahuddin, S., Abro, M., Kandhro, M., Salahuddin, L., Laghari, S. (2010). Correlation and path coefficient analysis of yield components of upland cotton [Gossypium hirsutum (L.)] sympodial. World Applied Sci. J., 8, 71-75.

Shrivastava, M. K., Shukla, R. S., Jain, P.K. (2001). Path coefficient analysis in diverse genotype of soybean [Glycine max (L.)]. Advances in Plant Sci., 4, 47-51.

Singh, R.K., Chaudhary, B.D. (1985). Biometrical methods in quantitative analysis. Kaljuni Publishers, India.

Singh, J., Yadava, H.S. (2000). Factors determining seed yield in early generation of soybean. Crop Res. Hisar., 20, 239-243

Udensi, O., Edu, E.A., Umana, E.J., Ikpeme, E.V. (2011a). Estimate of genetic variability in locally grown pulses [ Cajanus cajan (L.) Millsp and Vigna unguiculata (L.) Walp]: A pancea for sourcing superior genotypes. Pak. J. Bio. Sci., 14(6), 404-407.

Udensi, O., Umana, E.J., Edu, E.A., Ikpeme, E.V. (2011b). Screening locally grown pulses for proximate, anti-nutritive and mineral compositions: Indices for conservation and improvement. Int. J. Agric. Res., 6(6), 504-510.

Udensi, O., Ikpeme, E.V., Markson, A.A., Edu, E.A.B., Umana, E.J., Urua, I.S. (2010). Selection of soybean genotypes using morphological markers. Int. J. Current Research, 7, 5-8.

Vange, T., Moses, O.E. (2009). Studies on genetic characteristics of pigeon pea germplasm at Otobi, Benue State of Nigeria. World J. Agric. Sci., 5(6), 714-719

Yadev, G.C., Singh, P.K., Singh, B.B., Verma, R. (2001). Genetic variability and path coefficients in Urdbean. Indian J. Pulses Res., 14(2), 143-144.

(c) 2012 Udensi and Ikpeme; This is an Open Access article distributed under the terms of the Creative Commons Attribution License (http://creativecommons.org/licenses/by/3.0), which permits unrestricted use, distribution, and reproduction in any medium, provided the original work is properly cited. 